\title{
CHANGES IN THE STRUCTURE AND FLORISTIC COMPOSITION OF THE LIMESTONE GRASSLANDS AFTER CUTTING TREES AND SHRUBS AND MOWING
}

\author{
WOJCIECH BĄBA \\ Institute of Nature Conservation, Polish Academy of Sciences \\ Mickiewicza 33, 31-120 Cracow, Poland \\ e-mail:wbaba@iop.krakow.pl
}

(Recived: March 20, 2002. Accepted: January 13, 2003)

\begin{abstract}
The calcareous grasslands belong to the species-rich plant communities in Poland. Most of them are of anthropogenic origin and they need specific management (i.e. periodical cutting suckers of trees and shrubs, grazing or mowing) in order to protect their floristic diversity. Many of calcareous grasslands have been overgrown by shrubs as a result of cessation of traditional management. The aim of this study was to compare the structure and dynamics of xerothermic hazel shrub patches, which were undergoing secondary succession with patches where different management practices aiming at restoration of species-rich limestone grassland were applied. The managed plots had a significantly higher species richness than the control one. However, they strongly differed in their floristic composition from well-preserved limestone grasslands. There were also significant differences observed between both the managed plots. Too intensive management, particularly frequent mowing of herbs resulted in expansion of grass species such as Brachypodium pinnatum and Calamagrostis arundinacea and caused a sharp decline in species richness.

The species composition and turnover rate strongly depended on succesional stage (soil layer thickness) of plots at the start of the experiment. The deeper was the soil, the higher was the rate of species turnover and the smaller was the share of xerothermic and thermophilous species. The last mentioned group was dominated by species with a persistent seed bank in the soil, frequently colonizing anthropogenic habitats.
\end{abstract}

KEY WORDS: biodiversity, clearing, shrub management, RDA, restoration, secondary succession, species mobility.

\section{INTRODUCTION}

The encroachment of shrub into open grasslands as a result of their abandonment is a major threat to their biodiversity. It is also a major conservation problem for preserving of populations of rare and endangered species in most of Europaean countries (Fischer and Stöcklin 1997; Willems 1990).

Xerothermic grasslands on limestone rocks, which are classified as Origano-Brachypodietum association (following phytosociological nomenclature by Matuszkiewicz 2001) are among the richest in species plant communities in Poland and for this reason they are interesting for nature conservationists. They occur mainly in southern Poland where they occupy a zone between Festuca pallens-community on rock shelters, and hazel shrub (Peucedano cervariae-Coryletum). Limestone grasslands are built mainly by thermophilous species, such as Geranium sanguineum, Coronilla varia, Origanum vulgare, Asperula cynanchica and Inula hirta, in most cases confined to this specific habitat thus, many of them are rare or endangered (Medwecka-Kornaś and Kornaś 1992).

In the Ojców National Park (Poland), only remnants of the previously widespread xerothermic grasslands occur on limestone rocks and on the southern slopes of the valleys of the Prądnik and Sąspówka streams. They are classified as Festucetum pallentis, Origano-Brachypodietum and $\mathrm{Ko}$ elerio-Festucetum rupicolae associations (Michalik 1992). Most of them have been converted into thickets and forest in the last 30 years as a result of traditional management cessation (Michalik 1992; Michalik and Zarzycki 1995).

Hazel shrub patches overgrow S - SE facing slopes of calcareous rock. The constant species here are trees: Quercus robur, $Q$. petraea, Pinus sylvestris, Ulmus minor var. suberosa and Carpinus betulus, which cannot reach its normal height because of extreme conditions. They have thick, low trunks and crowns with long branches. Apart from the trees, the shrub layer is formed by Corylus avella- 
na, Rhamnus catharticus, Prunus avium and Cornus sanguinea. The herb layer shows a mosaic pattern of thermophilous and forest species. It is built by Trifolium rubens, Potentilla alba, Pulmonaria mollis, Laserpitium latifolium and Peucedanum cervaria, which appear in places where light can penetrate through the thick shrub canopy.

Most of the shrub communities are of anthropogenic origin and therefore rarely remain unchanged for a long time and cannot be maintained as plagioclimax (Ward 1990). In the Ojców National Park they had been maintained for centuries probably by periodical cutting of trees and shrubs with subsequent cutting and grazing. This type of management is similar to that applied in oak woodlands in the Mediterranean region, called "coppice" (Canullo 1991a, b). Only small patches of shrubs, growing on very steep, rocky slopes, where no management can be introduced, are probably natural communities. As a result of secondary succession most of the xerothermic shrub communities have slowly changed into oak-hornbeam (Tilio-Carpinetum) or beech forest (Carici-Fagetum convallarietosum $=$ Cruciata glabra-Fagus community).

The aims of this study were:

1) to compare changes in species composition and richness in hazel shrub patches without and under different management regimes aiming at restoration of species-rich xerothermic grassland;

2) to relate these changes to succesional stage of the community at the start of experiment.

\section{MATERIALS AND METHODS}

The study was carried out on the „Wernyhory” rock in the Ojców National Park, Kraków-Częstochowa Upland, southern Poland $\left[19^{\circ} 20^{\prime} \mathrm{E} ; 50^{\circ} 13^{\prime} \mathrm{N}\right.$ ] in the years $1996-$ 2000. The Park includes the valleys of Prądnik and Saspówka streams. The main rocky formations are Upper Jurassic massive limestone, which form numerous limestone crags. A part of the slopes and the Jurassic plateau are covered with loess. The mean annual temperature is high $\left(7.8^{\circ} \mathrm{C}\right)$ and the mean annual precipitation reach $663 \mathrm{~mm}$. The vegetation period lasts 213 days.

\section{Field surveys}

In September 1996 , three $10 \times 10 \mathrm{~m}$ permanent study plots were established in xerothermic hazel shrub on the „Wernyhory" rock in the northern part of the Park. One of them was treated as a control plot $(\mathrm{K})$. On the remaining plots all trees except for Quercus petraea were cut. In consecutive years on plots A and B all suckers were removed and additionally on plot B, the herb layers were mowed. In all the plots, changes in species composition were noted in $151 \times 1 \mathrm{~m}$ subplots (Fig. 1). The first recording was made in 1996, before trees and shrubs were cut. Then, records were made every year in one phenological season (flowering of Laserpitium latifolium and Libanotis pyrenaica). In case of the control plot, only the herb and shrub layers were recorded. In subplots, the number and percentage cover of the species were assessed.

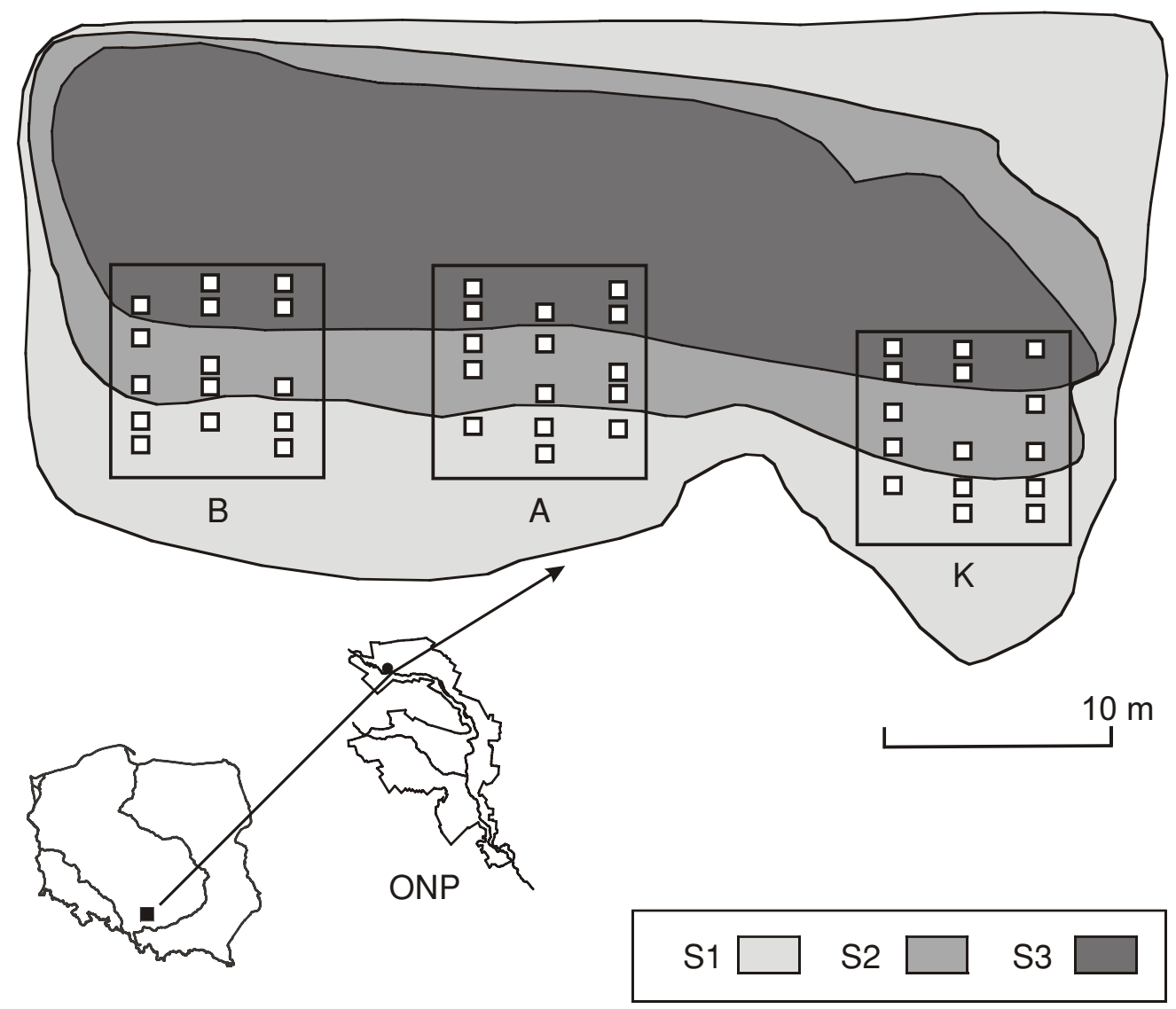

Fig. 1. Study area on the „Wernyhory” rock, Ojców National Park: B, A, K - permanent study plots, open squares - subplots on which vegetation changes were recorded; S1-S3 denotes soil of different thickness. ONP - Ojców National Park. 
To examine the correlation of species composition and dynamics with soil thickness, the subplots in particular plots were divided into three groups: S1: 3-10 cm; S2: 11$25 \mathrm{~cm} ; \mathrm{S} 3>25 \mathrm{~cm}$.

\section{Data analysis}

For all subplots the mean number and percentage cover of species of: Festuco-Brometea, Trifolio-Geranietea, Rhamno-Prunetea, Querco-Fagetea classes were calculated. Moreover, species diversity was determined according to Shannon-Wiener formula (Hill 1973):

$$
H^{\prime}=-\sum_{i=1}^{S} p_{i} \log p_{i}
$$

and the structure of domination by means of the Simpson index:

$$
C^{\prime}=-\sum_{i=1}^{S} p_{i}{ }^{2}
$$

where $\mathrm{p}_{\mathrm{i}}=\mathrm{n}_{\mathrm{i}} / \mathrm{N} ; \mathrm{n}_{0}$ is $\%$ cover of the $\mathrm{i}$-th species, $\mathrm{N}-$ is the sum of $\%$ cover of all species in a sample.

Differences in the number of species and H' value between years, management type and soil thickness were tested with the three-way ANOVA. Interactions between factors were tested with the Tuckey HSD test (Sokal and Rohlf 1981). Prior to the analysis the normal distribution of variables was tested and then they were log-transformed to meet the ANOVA assumption. Because the distributions of all other variables were not-normal (mainly because of a lot of zeroes which occurred in the data) a non-parame- tric tests was used. The changes between years were tested by means of the Friedman test, between managed and nonmanaged plots by means of the Kruskal-Wallis test and between the particular management types - with the U MannWhitney test.

To compare species mobility and species turnover rate in particular plots, the mean cumulative species numbers in subplots were calculated (van der Maarel and Sykes 1993, 1997). Additionally, in all the studied plots, the mean number of immigrant (= species, which appeared in particular plot during study period), extinct (= species not present in the plot during the two consecutive years) and persistent species were calculated.

To assess the main envinromental preferences of species, mean the Ellenberg indicator values $(\mathrm{L}-$ light, $\mathrm{N}-$ nutrient, $\mathrm{R}$ - soil acidity) were calculated (Lindacher et al. 1995).

In order to examine the dependence of species cover on the type of management (plots), time and soil thickness the Redundancy Analysis (RDA, CANOCO program; Jongman \& ter Braak 1995) was applied. This method is based on PCA (Principal Component Analysis), in which linear dependency of species cover on environmental factors is constrained. If environmental gradients are short, as is the case in my study, this method gives good results in reflecting the true variability of the data. Several explanatory dummy variables were used: years (1997-2000), type of management ( $\mathrm{K}$ - control plot; A - suckers removal; B suckers removal + mowing), variables, which grouped particular plots in years (K 97... K 00; A 97... A 00; B 97...B 00), and variables, grouped subplots according to soil thickness (S1; S2; S3). The Monte Carlo analysis with 1000 permutations was used to test the significance of this

\begin{tabular}{|c|c|c|c|c|c|c|}
\hline 1-PLOT, 2-S, 3-YEARS & $\begin{array}{c}\text { df } \\
\text { effect }\end{array}$ & $\begin{array}{c}\text { MS } \\
\text { effect }\end{array}$ & $\begin{array}{c}\text { df } \\
\text { error }\end{array}$ & $\begin{array}{l}\text { MS } \\
\text { error }\end{array}$ & $\mathrm{F}$ & $\mathrm{P}$ \\
\hline PLOT & 2 & 14.05 & 36 & 0.56 & 24.91 & $* * *$ \\
\hline $\mathrm{S}$ & 2 & 3.43 & 36 & 0.56 & 6.08 & $* * *$ \\
\hline YEARS & 3 & 4.85 & 108 & 0.18 & 26.67 & $* * *$ \\
\hline PLOT $\times S$ & 4 & 1.18 & 36 & 0.56 & 2.09 & ns \\
\hline PLOT $\times$ YEARS & 6 & 1.37 & 108 & 0.18 & 7.55 & $* * *$ \\
\hline $\mathrm{S} \times \mathrm{YEARS}$ & 6 & 0.37 & 108 & 0.18 & 2.07 & ns \\
\hline $\mathrm{PLOT} \times \mathrm{S} \times \mathrm{YEARS}$ & 12 & 0.08 & 108 & 0.18 & 0.48 & ns \\
\hline
\end{tabular}
model.

TABLE 1. Three-way repeated measures ANOVA for effect of plots, years and soil thickness on Shannon-Wiener H' value.

\begin{tabular}{|c|c|c|c|c|c|c|}
\hline 1-PLOT, 2-S, 3-YEARS & $\begin{array}{c}\text { df } \\
\text { effect }\end{array}$ & $\begin{array}{c}\text { MS } \\
\text { effect }\end{array}$ & $\begin{array}{c}\text { df } \\
\text { error }\end{array}$ & $\begin{array}{c}\text { MS } \\
\text { error }\end{array}$ & $\mathrm{F}$ & $\mathrm{P}$ \\
\hline PLOT & 2 & 1191.52 & 36 & 23.36 & 50.99 & $* * *$ \\
\hline $\mathrm{S}$ & 2 & 174.15 & 36 & 23.36 & 7.45 & $* * *$ \\
\hline YEARS & 3 & 308.02 & 108 & 4.07 & 75.63 & $* * *$ \\
\hline PLOT $\times S$ & 4 & 32.03 & 36 & 23.36 & 1.37 & ns \\
\hline PLOT $\times$ YEARS & 6 & 24.38 & 108 & 4.07 & 5.98 & $* * *$ \\
\hline $\mathrm{S} \times \mathrm{YEARS}$ & 6 & 7.29 & 108 & 4.07 & 1.79 & ns \\
\hline PLOT $\times S \times$ YEARS & 12 & 4.14 & 108 & 4.07 & 1.01 & ns \\
\hline
\end{tabular}

$0.05>\mathrm{P}>0.01 ; * * 0.01>\mathrm{P}>0.001 ; * * * 0.001<\mathrm{P} ; \mathrm{ns}-$ not significant

TABLE 2. Three-way repeated measures ANOVA for effect of plots, years and soil thickness on mean number of species per $1 \mathrm{~m}^{2}$.

$0.05>\mathrm{P}>0.01 ; * * 0.01>\mathrm{P}>0.001 ; * * * 0.001<\mathrm{P} ; \mathrm{ns}-$ not significant 
TABLE 3. Pairwise comparison (Tuckey HSD test) of plots and years on H'value. Numbers in table denote the probability of differences between plots and years. Only significant $(\mathrm{P} \leq 0.05)$ interactions are shown.

\begin{tabular}{|c|c|c|c|c|c|c|c|c|c|c|c|c|c|c|c|}
\hline \multicolumn{4}{|c|}{$\begin{array}{l}\text { H' } \\
\text { PLOT } \times \text { YEARS }\end{array}$} & (1) & (2) & (3) & (4) & (5) & (6) & (7) & (8) & (9) & (10) & (11) & (12) \\
\hline \multicolumn{4}{|c|}{ mean } & 1.65 & 1.74 & 1.79 & 1.83 & 2.26 & 2.58 & 2.89 & 2.83 & 1.84 & 2.33 & 2.93 & 3.41 \\
\hline K & $\ldots$ & 1997 & (1) & & & & & & 0.001 & 0.001 & 0.001 & & 0.001 & 0.001 & 0.001 \\
\hline K & $\ldots$ & 1998 & (2) & & & & & 0.05 & 0.001 & 0.001 & 0.001 & & 0.01 & 0.001 & 0.001 \\
\hline K & $\ldots$ & 1999 & (3) & & & & & & 0.001 & 0.001 & 0.001 & & 0.04 & 0.001 & 0.001 \\
\hline K & $\ldots$ & 2000 & (4) & & & & & & 0.001 & 0.001 & 0.001 & & & 0.001 & 0.001 \\
\hline A & $\ldots$ & 1997 & (5) & & 0.05 & & & & & 0.01 & 0.02 & & & 0.001 & 0.001 \\
\hline A & $\ldots$ & 1998 & (6) & 0.001 & 0.001 & 0.001 & 0.001 & & & & & 0.001 & & & 0.001 \\
\hline A & $\ldots$ & 1999 & (7) & 0.001 & 0.001 & 0.001 & 0.001 & 0.01 & & & & 0.001 & 0.02 & & 0.05 \\
\hline A & $\ldots$ & 2000 & (8) & 0.001 & 0.001 & 0.001 & 0.001 & 0.02 & & & & 0.001 & & & 0.02 \\
\hline B & $\ldots$ & 1997 & (9) & & & & & & 0.001 & 0.001 & 0.001 & & & 0.001 & 0.001 \\
\hline B & $\ldots$ & 1998 & (10) & 0.001 & 0.01 & 0.04 & & & & 0.02 & & & & 0.01 & 0.001 \\
\hline B & $\ldots$ & 1999 & (11) & 0.001 & 0.001 & 0.001 & 0.001 & 0.001 & & & & 0.001 & 0.01 & & \\
\hline B & $\ldots$ & 2000 & (12) & 0.001 & 0.001 & 0.001 & 0.001 & 0.001 & 0.001 & 0.05 & 0.02 & 0.001 & 0.001 & 0.10 & \\
\hline
\end{tabular}

\section{RESULTS}

\section{Changes in species richness and diversity}

The results of the three-way ANOVA showed significant effects of plots, soil thickness, years and PLOT $\times$ YEARS interaction on species number and H' value of the studied plots. The managed plots were characterized by a higher overall species richness and species diversity $\left(\mathrm{H}^{\prime}\right)$ as compared to the control (Tables 1,2$)$. These differences were highly significant $(\mathrm{P}<0.001)$. The pairwise mean comparisons (Tuckey HDS test) showed no significant differences in number of species between the two managed plots. The highest H' value was found in the last year of study on the plots on which every year suckers were removed (subsequently referred to as A plot), although differences between them and cuting and mowing (B plot) were insignificant (Table 3).

In the control plot, the number and percentage of species cover were low and have not been changed significantly throughout the study period, except of forest species. On the contrary, on both managed plots, the number and percentage cover of xerothermic and thermophilous species increased very quickly, especially in the third year of experiment. In plot $A$, the number of forest species slightly increased, but their cover decreased, although that change was not significant (Table 4). In plot B, the number and percentage cover of forest species were significantly lower than in plot A. In plot A, the high and thick upper part of the herb layer strongly shaded the forest species, growing beneath their canopy, in a similar way as trees did. The number of light-demanding species was higher in both managed plots than in the control, and in the cut and mown plot (B) than in the cut plot (A) (Table 4).

\section{Dynamics of species and turnover rate}

The rate of species number accumulation was much higher in both managed plots as compared to the control. In the managed plots, the highest species accumulation was in the first two years, after trees and shrubs removal. Then it slowly declined, because of the shortage of empty space, suitable for colonization. (Fig. 2). The highest participation of immigrant species on both managed plots pointed out colonization as the main process which took place there (Table 5).
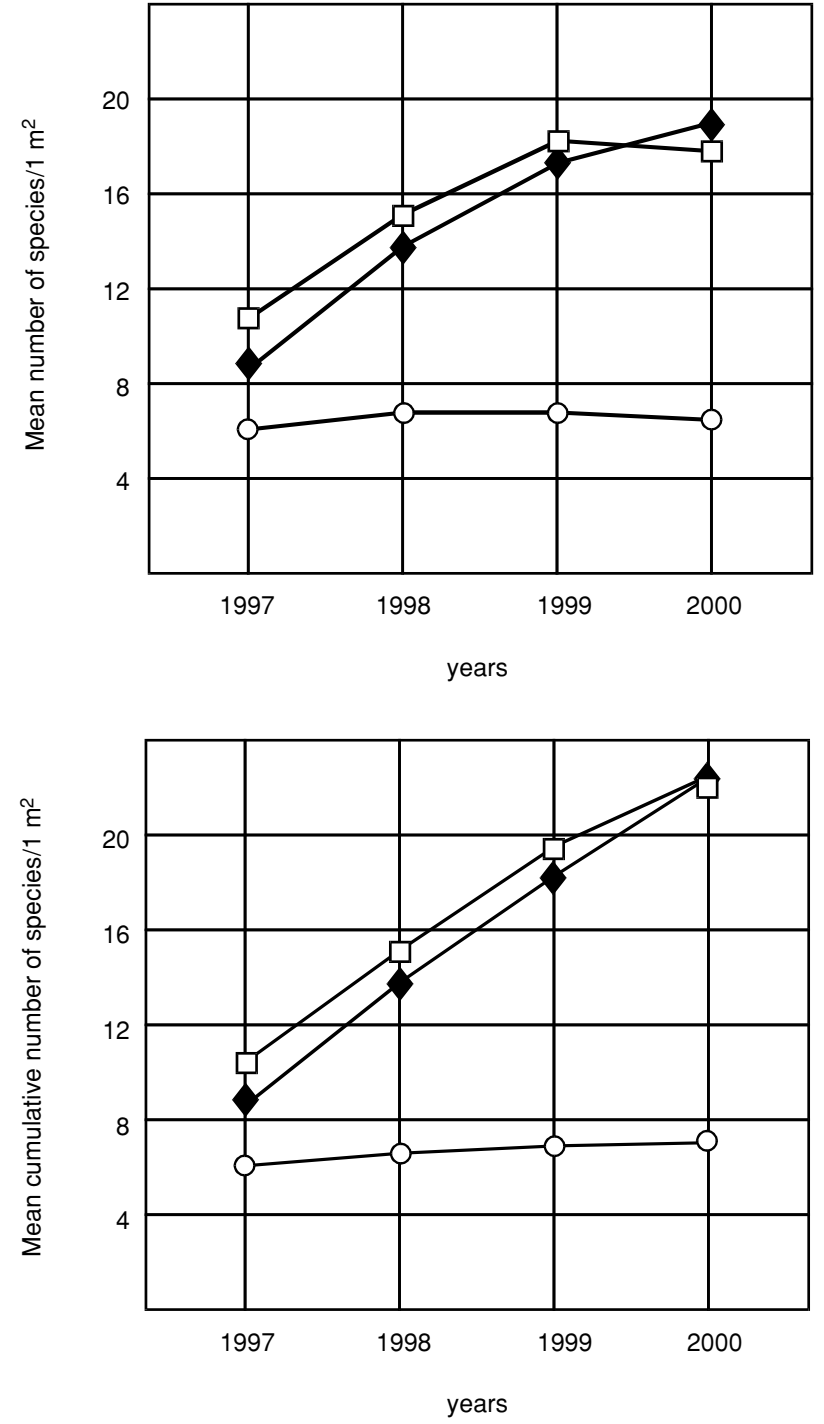

Fig. 2. Changes in mean species number and mean cumulative species number in control (open circles), cut (diamonds) and cut and mown (open squares) plots. 


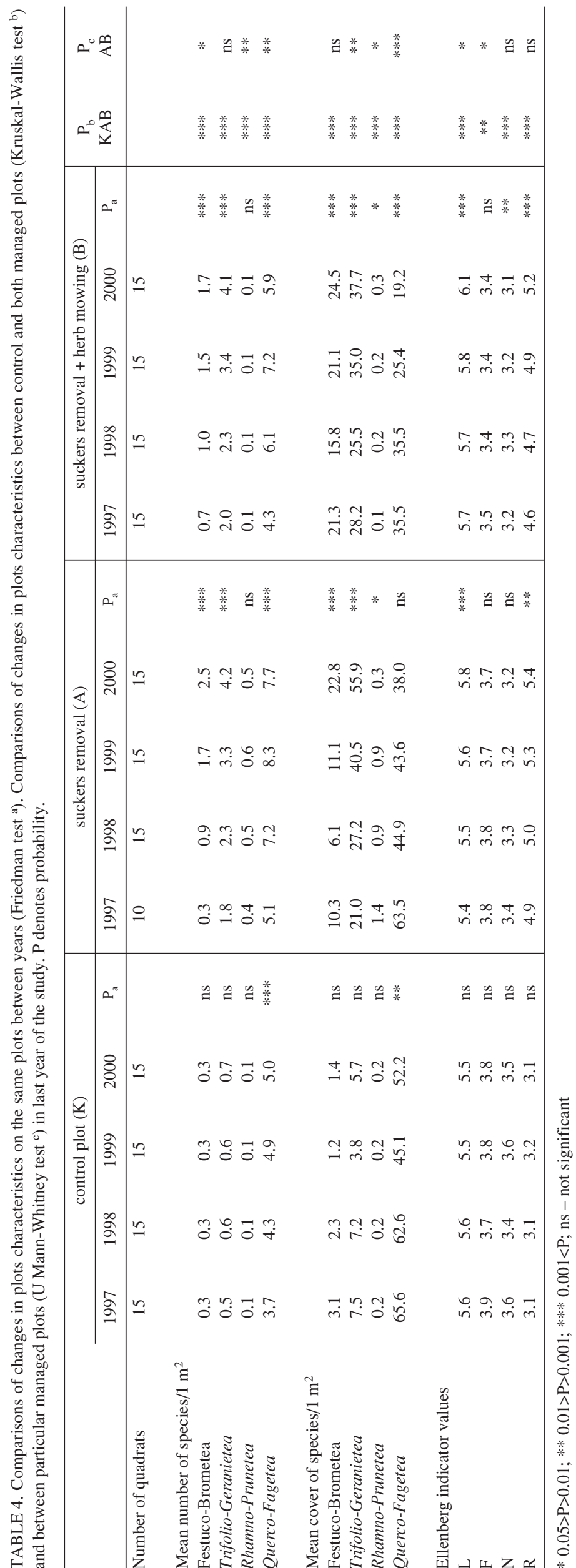

\section{Changes in floristic composition of the plots}

The first two RDA axes $\left(\lambda_{1}=0.06 ; \lambda_{2}=0.04\right)$ accounted for $12 \%$ total variation in species cover and $65.8 \%$ fitted species data $(\mathrm{P}<0,01$; Monte Carlo permutation test). To make the diagram more clear, only the years 1997, 1999 and 2000 were taken into account (Fig. 3). The results of RDA ordination of plots show that the rate and direction of changes strongly depend on both the types of management applied to the plots (thus management intensity) and soil depth, which refer to successional stage of the community. The first RDA axis which represents a gradient of soil nutrients, strongly separates plot $\mathrm{A}$, which in the first year after tree cutting was occupied by forest species, from the remaining ones, dominated by species characteristic to habitats poor in nitrogen and phosphorus.

The second RDA axis showed changes in time and separated species according to their distribution along gradient of soil thickness (Fig. 3). A comparison of the position of centroids, which grouped plots in the particular years, showed that the rate of changes in species cover was highest on managed plots, especially in the first two years after cutting the trees and shrubs. On plot $\mathrm{A}$, in the first year of experiment, the herb layer was dominated by Melampyrum nemorosum and Cruciata glabra. In the two consecutive years, the percentage cover of the former species decreased rapidly. Herbs were divided into two layers - a higher one, dominated by Laserpitium latifolium and perennial grasses, which strongly shaded the lower one occupied by Hepatica nobilis, Anemone nemorosa, Carex digitata, Viola reichenbachiana and $V$. mirabilis (Fig. 3). In the more intensively managed plot $\mathrm{B}$ the rate of changes in species cover was much slower. In this plot, on the contrary, a strong expansion of perennial grass Brachypodium pinnatum and thermophilous species was observed. Intensive moving caused also a decline in the abundance of forest species such as Melica nutans, Lathyrus vernus and Anemone nemorosa.

Within the managed plots, patches of bare ground were colonized mainly by species from the close neigbourhood. Therefore on both plots A and B, the distribution of xerothermic and thermophilous species was confined in the last year of the study to the external, narrow zone (S1) between the former xerothermic scrub and well-preserved calcareous grasslands. They never reached the inner part of the plots (S2, Figs 1, 3), which was occupied mainly by forest species.

On plot A an encroachment of the light-demanding species was observed, which are representatives of thermophilous shrub communities, such as: Hieracium murorum, Hieracium bifidum, Peucedanum cervaria, Trifolium rubens. The last two species are rare and of high conservation interest. The active protection measures applied to both of these plots caused an increase in the \% cover of light-demanding species, such as Chamaecytisus supinus, Inula hirta, I. salicina, Geranium sanguineum and Origanum vulgare. On the other hand, a considerable increase in 


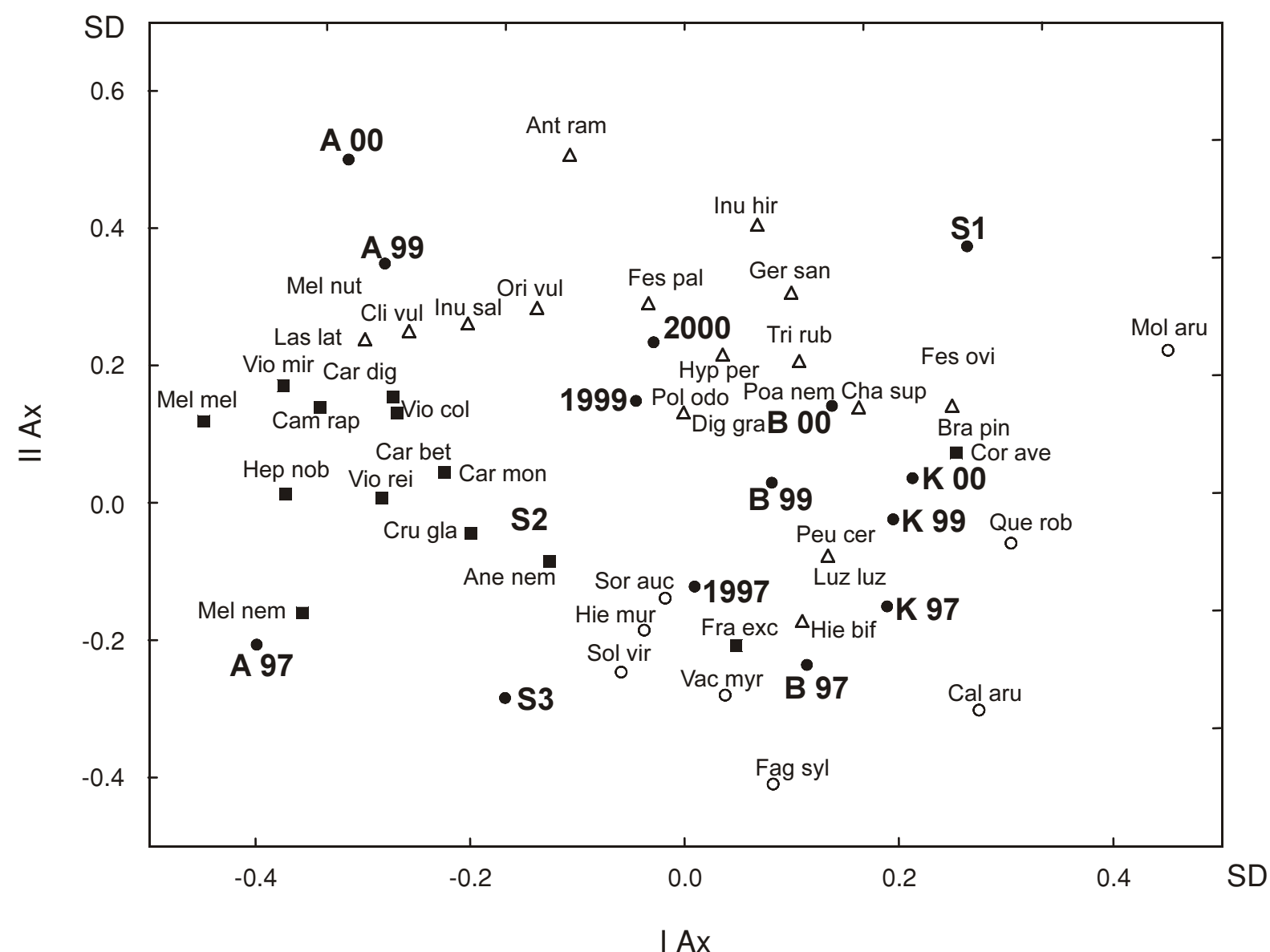
$\Delta 1$
- 2
$\circ 3$

Fig. 3. Biplot of species and centroids of years, plot by year combinations and quadrat by soil thickness combinations for the non-managed and managed plots. The diagram shows the first two RDA axes, which explained 12 and 65, 8\% of variance of species data and fitted species data. 1 - Thermophilous species belong to Festuco-Brometea and Trifolio-Geranietea classes; 2 - forest species (Querco-Fagetea); 3 - others. Species abbreviations are based on three letters of the genus and species.

TABLE 5. Species dynamics and turnover rate in control (K). cut (A) and cut and mown (B) plots. I - Mean number of species occupy the same subplots during study periods; II - species, which disappeared during study period; III - species, which appeared during the study period; IV - other species.

\begin{tabular}{|c|c|c|c|c|c|c|c|c|c|}
\hline \multirow[t]{2}{*}{ Species group } & \multicolumn{3}{|c|}{$\mathrm{K}$} & \multicolumn{3}{|c|}{$\mathrm{A}$} & \multicolumn{3}{|c|}{ B } \\
\hline & mean & SD & $\%$ & mean & SD & $\%$ & mean & SD & $\%$ \\
\hline I & 5.4 & 2.4 & 52.4 & 9.5 & 2.8 & 32.94 & 7.8 & 2.5 & 30.6 \\
\hline III & 2.9 & 2.2 & 28.2 & 9.1 & 3.8 & 44.71 & 8.9 & 3.7 & 36.7 \\
\hline IV & 1.4 & 1.5 & 13.6 & 2.1 & 1.5 & 17.65 & 3.0 & 1.5 & 22.0 \\
\hline
\end{tabular}

the percentage cover of invasive grass species: Calamagrostis arundinacea and Molinia arundinacea were recorded.

\section{DISCUSSION}

As it was already shown in similar studies (Dzwonko and Loster 1998; Ward 1990), the rate of species colonization and species turnover was highest in the first two years after the trees had been cut. These changes were the result of both the tremendous alteration in the light conditions and high availability of microsites for species, which were already established and those from the nearest neighbourhood. In the managed plots the species richness and H' value were higher than in the non-managed ones. The mean species number was doubled in those plots during the four years after trees and shrubs had been cut. In spite of the applied management measures, the number of xerothermic and thermophilous species on the managed plots was low, and forest species dominated throughout the study period. The floristic composition and turnover rate of species strongly depended on soil thickness, corresponding to the succesio- 


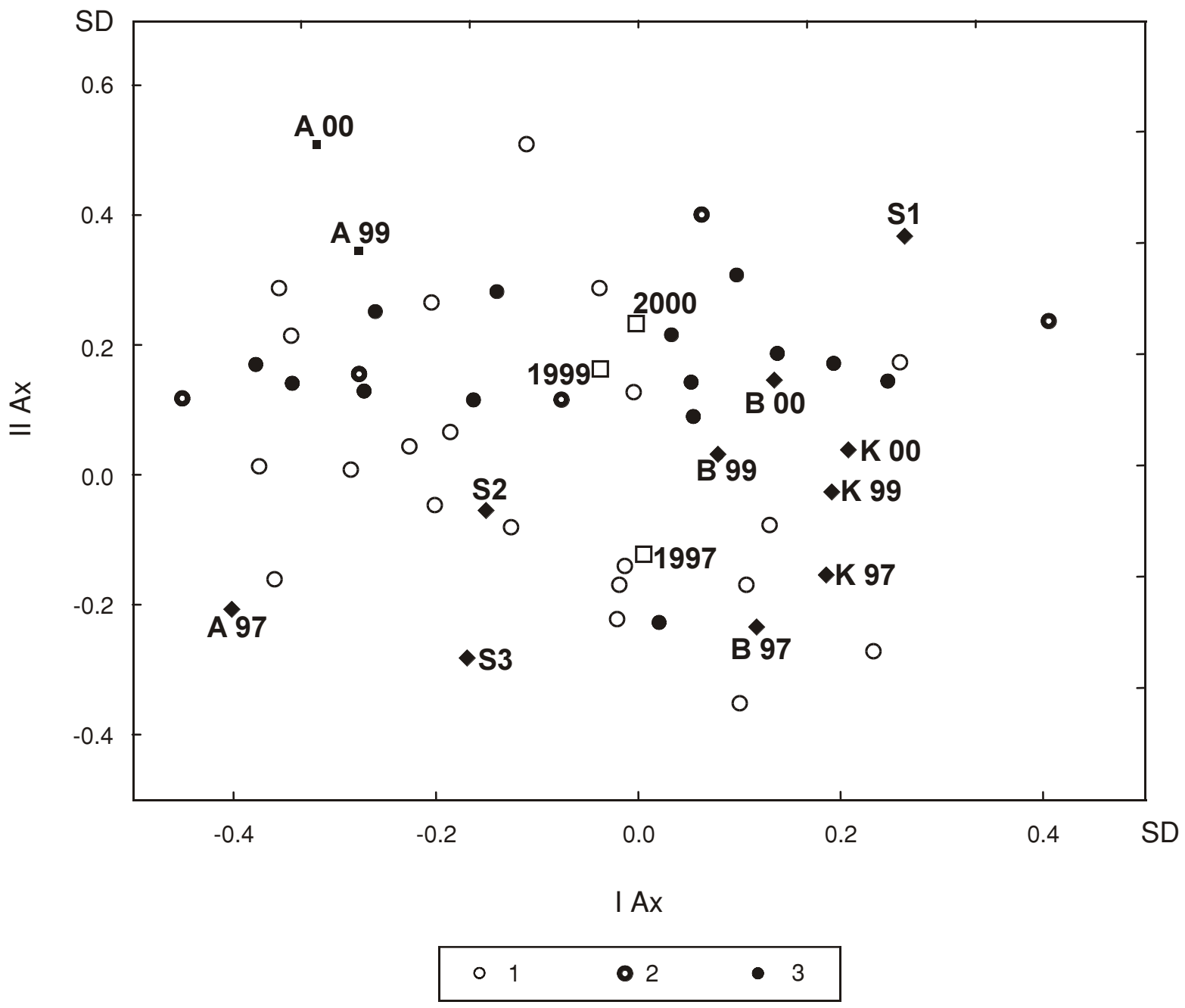

Fig. 4. Biplot of species and centroids of years, plot by year combinations and quadrat by soil thickness combinations for the non-managed and managed plots. Points represent species from figure 4. They are divided according to soil seed bank type they formed (Thompson et al. 1997): 1 - species with transient seed bank, 2 - short-term persistent and 3 - long-term persistent seed bank.

nal stage of the patches of vegetation within the plots. The highest rate of species turnover was found for subplots on thick soil, shaded by trees and shrubs, but they strongly differed in species composition from subplots on shallow soil. Thermophilous species occupied mainly subplots established in the shallow-soil zone (S1), in the vicinity of well-preserved xerothermic vegetation patches. This is because most of these species have a short dispersal mode, within 1.5-2.5 meter zone around mother plant (Hensen 1997; Stampfli and Zeiter 1999). It seems that xerothermic and thermophilous species colonize restored plots mainly in a vegetative way or as seed rain (Jefferson and Usher 1987; Willems and Bik 1998). The seed bank plays a rather insignificant role in restoration of species-rich xerothermic grasslands (Barbaro et al. 2001; Dutoit and Alard 1995; Davies and Waite 1998). Many studies on seed banks have shown the disparity between the species composition of the seed bank and the above-ground vegetation (Chippindale and Milton 1934; Graham and Hutchings 1988). It could be explained by the fact that most of calcareous grasslands species don't create persistent seed banks (type III) (Thompson et al. 1996), and their seeds cannot survive under a dense shrub canopy (Davies and Waite 1998). Another reason is the low seed dispersal by many grasslands species (Verkaar et al. 1983). As is shown in Figure 4, some xerothermic species, such as: Origanum vulgare and Hypericum perforatum, which colonise restored plots, are an exception. These species are usually main components of the persistent seed bank from which they regenerate after disturbances (Grime 1990, 2001; Dutoit and Alard 1995). Apart from xerothermic grassland, they are often encountered in anthropogenic plant communities, which develop on roadsides and escarpments with similar habitat conditions.

Klimeš (1999) suggests shrub density as one of the factors which play a significant role in restoration of speciesrich xerothermic grasslands from shrubland. Unexpectedly, the thicker it is, the weaker the herb layer is developed and as a result - after shrub clearing - the more gaps of bare soil are accessible to colonization by xerothermic species.

On the other hand, in my surveys, the fragments of plots on thick and rich in nutrients soils, which were heavily shaded, in spite of the high rate of species turnover, differed distinctly in their floristic composition from those situated close to the well-preserved xerothermic grasslands. 
Only plots which represent the early stages of secondary succession, situated close to the sources of propagules, seem to regenerate quickly the floristic composition typical of species-rich grasslands (Dzwonko and Loster, 1998).

Another important factor, influencing the species composition of restored xerothermic vegetation, is the type and intensity of management. The two managed plots differed strongly in species richness and composition in spite of similar habitat conditions. In many papers it is stressed, that restoration of species-rich calcareous grasslands is not possible when only trees and shrubs have been cleared (Kiefer and Poschlod 1996; Dzwonko and Loster 1998), because these plots are quickly being overgrown by suckers of woody species. An additional management, such as mowing and grazing is needed in order to protect the species diversity. However, when the applied management is too intensive and one-sided, it causes a rapid decline in species richness. During the study it was proved that although intensive mowing caused a decline in the number of mesophilous forest species, it led also to an increase in the dominance of strongly invasive grasses - Calamagrostis arundinacea, Brachypodium pinnatum and Molinia arundinacea. These species can displace most of the xerothermic ones. Among the thermophilous species, whose abundance significantly increased in mowed plots, prevailed species with a strongly developed root system: Geranium sanguineum, Trifolium rubens and Chamaecytisus supinus. This trait enables them to regenerate in conditions of repeatable disturbances.

It seems that the clearing of shrubs by subsequent periodical mowing or grazing of herbs enable to restore a mosaic of habitats - calcareous grasslands and shrubs. This mosaic is suitable for colonization by species with different life history traits, which decide on biodiversity and stability of the xerothermic vegetation of limestone rocks.

\section{ACKNOWLEDGEMENTS}

I'm very grateful to Prof. Stefan Michalik, Prof. Kazimierz Zarzycki and Prof. Zbigniew Dzwonko for stimulating discussion and comments on my PhD Thesis. The autor is also very grateful to dr Agnieszka Kompała and dr Małgorzata Makomaska-Juchiewicz for English translation.

\section{LITERATURE CITED}

BARBARO L., DUTOIT T., COZIC P. 2001. A six-year experimental restoration of biodiversity by shrub-clearing and grazing in calcareous grasslands of the French Prealps. Biodiversity and Conservation 10: 119-135.

CANULLO R. 1991a. The map of vegetation structure of a copicewood in the nature reserve of the Fiastra Abbey (Central Ita1y). Phytocoenosis, Suppl. Cartogr. Geobot 3: 195-198.

CANULLO R. 1991b. Vegetation structure and regeneration process in a mixed deciduous coppice in the Central Apenines (Italy). Phytocoenosis, Suppl. Cartogr. Geobot 3: 199-207.

CHIPPINDALE H.G., MILTON W.E.J. 1934. On the viable seeds present in the soil beneath pastures. Journal of Ecology 22: 508-531.

DAVIES A., WAITE S. 1998. The persistence of calcareous grassland species in the soil seed bank under developing and established shrub. Plant Ecology 136: 27-39.
DUTOIT T., ALARD D. 1995. Permanent seed banks in chalk grassland under various management: their role in the restoration of species-rich plant communities. Biodiversity and Conservation 4: 939-950.

DZWONKO Z., LOSTER S. 1998. Dynamics of species richness and composition in a limestone grassland restored after tree cutting. Journal of Vegetation Sciences 9: 387-394.

FISCHER M., STÖCKLIN J. 1997. Local extinctions of plants in remnants of extensively used calcareous grasslands 19501985. Conservation Biology 11: 727-737.

GRAHAM D.J., HUTCHINGS M.J. 1988. A field investigation of germination from the seed bank of a chalk grassland ley on former arable land. Journal of Applied Ecology 25: 253-263.

GRIME J.P. 1990. Mechanisms promoting floristic diversity in calcareous grasslands. In: Calcareous grasslands - Ecology and Management. Hiller SH, Walton DWH and Wells DA (ed.). Bluntisham Books, Bluntisham, Huntington, pp 51-56.

GRIME J.P. 2001. Plant strategies, Vegetation Proceses and Ecosystem Properties. John Willey and Sons, pp. 465.

HENSEN I. 1997. Life strategy systems of xerothermic grasslands - mechanisms of reproduction and colonization within Stipetum capillatae s.1. and Adonido-Brachypodietum pinnati. Feddes Repertorium 10: 425-452.

HILL M.O. 1973. Diversity and evennes: a unifying notation and its consequences. Ecology 54: 427-432.

JEFFERSON R.G., USHER M.B. 1987. The seed bank of disused chalk quarries in the Yorkshire Wolds, England: implications for conservation management. Biological Conservation 47: 123-136.

JONGMAN R.H.G., TER BRAAK C.J.F., van Tongeren O.F.R. 1995. Data analysis in community and landscape ecology. Pudoc, Wageningen, pp 91-173.

KIEFER S., POSCHLOD P. 1996. Restoration of fallow or afforested calcareous grasslands by clear-cutting. In: Species survival in Fragmented Landscapes. Settele J., Margules C.R., Poschlod P., Henle K. (eds.)., Kluwer Academic Publishers, Dordrecht, The Netherlands, pp 219-229.

KLIMEŠ L. 1999. Small-scale plant mobility in a species-rich grassland. Journal of Vegetation Science 10: 209-218.

LINDACHER R., BÖCKER R., BEMMERLEIN-LUX F.A., KLEEMANN A., HAAS S. 1995. PHANART. Datenbank der gefässpflanzen Mitteleuropas. Erklärung der Kennzahlen, Aufbau und Inhalt. Veröffentlichungen des Geobotanischen Institutes ETH, Stiftung, Rubel 125: 1-436.

MATUSZKIEWICZ W. 2001. Przewodnik do oznaczania zbiorowisk roślinnych Polski, PWN, Warszawa, pp. 537 (in Polish).

MEDWECKA-KORNAŚ A., KORNAŚ J. 1992. Ojców National Park. Veröffentlichungen des Geobotanischen Institutes ETH, Stiftung, Rubel 107: 49-59.

MICHALIK S. 1992. Tendencies of anthropogenic changes and a programme for active protection of vegetation in the Ojców National Park (S. Poland). Veröffentlichungen des Geobotanischen Institutes ETH, Stiftung, Rubel 107: 60-81.

MICHALIK S., ZARZYCKI K. 1995. Management of xerothermic grasslands in Poland: botanical approach. Colloques Phytosociologiques 24: 881-895.

SOKAL R., ROHLF F. 1995. Biometry. The principles and practice of statistics in biological research, third edition, pp. 887. W. H. Freeman and Company, New York.

STAMPFLI A., ZEITER M. 1999. Plant species decline due to abandonment of meadow cannot be easily be reversed by mowing. A case study from southern Alps. Journal of Vegetation Science 10: 151-164.

THOMPSON K., HILLER S.H., GRIME J.P., BOSSARD C.C., BAND S.R. 1996. A functional analysis of a limestone grassland community. Journal of Vegetation Science 7: 371-380.

VERKAAR H.J., SCHENKEVELD A.J., VAN DE KLASHORST M.P. 1983. The ecology of short-lived forbs in chalk grasslands: dispersal of seeds. New Phytologist 95: 335-344. 
VAN DER MAAREL E., SYKES M.T. 1993. Small-scale plant species turnover in a limestone grassland: the carousel model and some comments on the niche concept. Journal of Vegetation Science 4: 179-188.

VAN DER MAAREL E., SYKES M.T. 1997. Rates of small-scale species mobility in alvar limestone grassland. Journal of Vegetation Science 8: 199-208.

WARD L.K. 1990. Management of grassland - scrub mosaics. In: Calcareous grasslands - Ecology and Management. Hiller
S.H., Walton D.W.H., Wells D.A. (eds.), Bluntisham Books, Bluntisham, Huntington, pp. 134-139.

WILLEMS J.H. 1990. Calcareous grasslands in continental Europe. In: Calcareous grasslands - Ecology and Management. Hiller S.H., Walton D.W.H., Wells D.A. (eds.), Bluntisham Books, Bluntisham, Huntington, pp. 3-10.

WILLEMS J.H., BIK L.P.M. 1998. Restoration of high species density in calcareous grassland: the role of seed rain and seed bank. Applied Vegetation Science 1: 91-100.

\section{STRUKTURA I DYNAMIKA ZARASTAJĄCYCH MURAW KSEROTERMICZNYCH PO WYCIECCIU DRZEW I KRZEWÓW}

\section{STRESZCZENIE}

Murawy naskalne i kserotermiczne należą do jednych z najbogatszych w gatunki zbiorowisk roślinnych w Polsce. Większość z nich jest pochodzenia półnaturalnego i do zachowania składu florystycznego wymaga okresowego usuwania drzew i krzewów oraz ich odrośli. Głównym celem przeprowadzonego eksperymentu, było porównanie struktury i dynamiki zarośli kserotermicznych bez zabiegów oraz poddanych ochronie aktywnej, która zmierzała do odtworzenia składu florystycznego typowego dla muraw. Wykazano, że poletka użytkowane charakteryzowały się istotnie wyższym bogactwem florystycznym w porównaniu z poletkiem kontrolnym, jednak ich skład florystyczny znacznie odbiegał od typowego dla bogatych florystycznie muraw. Zbyt intensywne użytkowanie, zwłaszcza koszenie runa, powodowało wzrost udziału ekspansywnych traw: Brachypodium pinnatum i $C a$ lamagrostis arundinacea i w konsekwencji spadek różnorodności gatunkowej użytkowanego poletka. Tempo wymiany gatunków oraz skład florystyczny silnie zależały od stadium sukcesyjnego (głębokości gleby) w jakim znajdował się płat roślinności na początku eksperymentu: im większa była głębokość gleby tym większe tempo wymiany gatunków oraz mniejszy udział gatunków kserotermicznych i ciepłolubnych. Wśród tych ostatnich, dominowały gatunki o trwałym banku nasion w glebie, często kolonizujące siedliska antropogeniczne. Optymalnym zabiegiem dla utrzymania mozaiki zarośli i muraw jest usuwanie drzew i krzewów, połączone z okresowym wykaszaniem lub wypasaniem runa. Przeprowadzone zabiegi są jednak niewystarczające do odtworzenia bogatego składu gatunkowego, jeśli nie ma stałego dopływu diaspor gatunków kserotermicznych („,deszczu nasion”) z najbliższego sąsiedztwa odtwarzanego płatu, gdyż nieliczne tylko gatunki murawowe tworzą trwały bank nasion w glebie.

SŁOWA KLUCZOWE: bioróżnorodność, RDA, sukcesja wtórna, mobilność gatunków. 